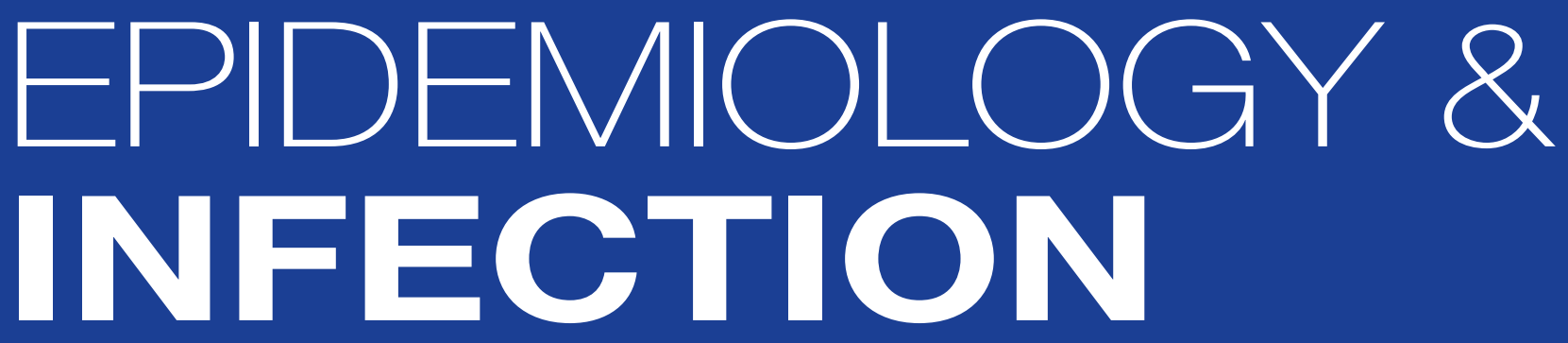

journals.cambridge. org/hyg
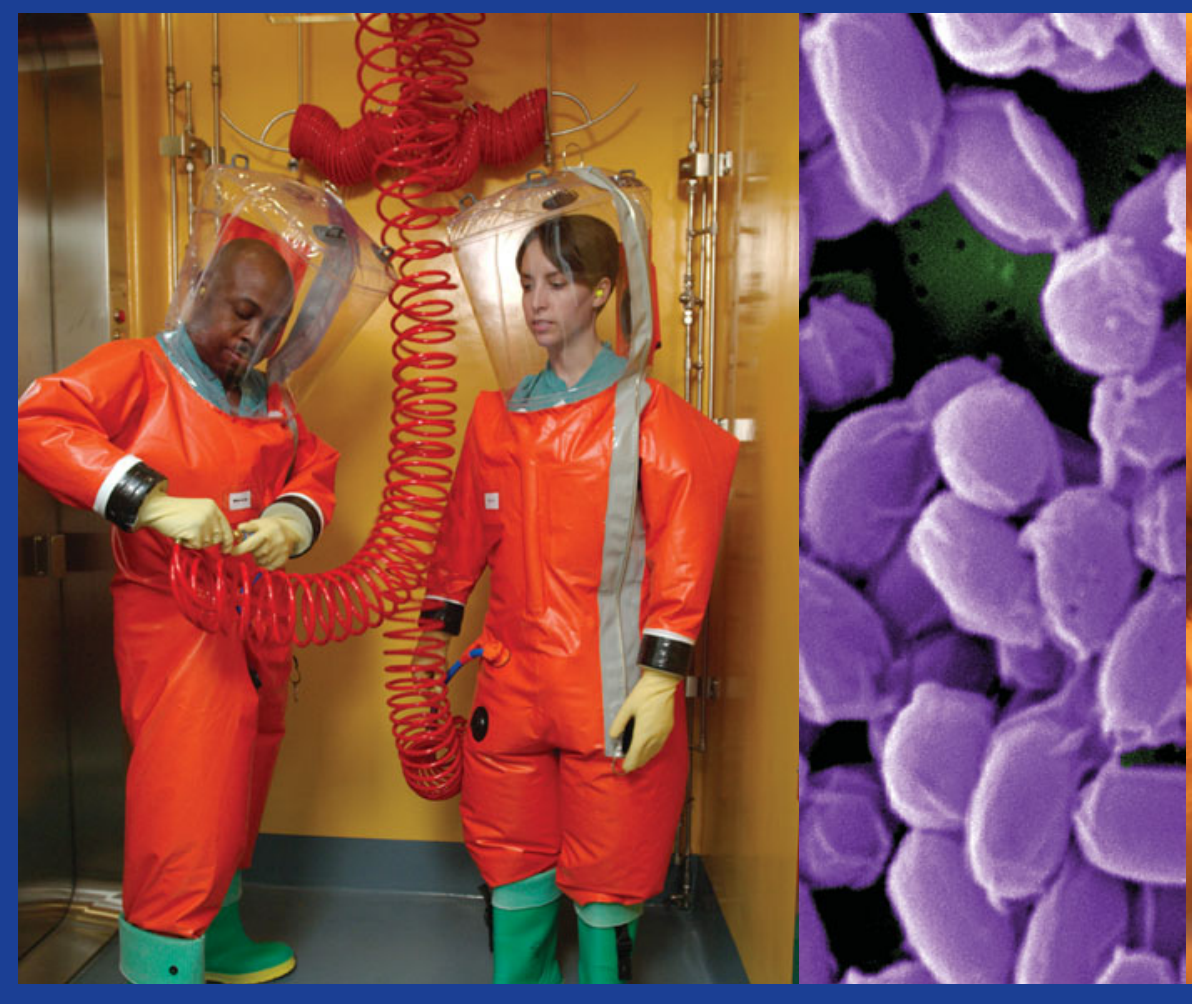


\section{Epidemiology and Infection}

\section{SENIOR EDITOR/MANAGING EDITOR}

Professor Norman Noah

London School of Hygiene and Tropical Medicine, Keppel Street, London WC1E 7HT, UK

\section{EDITORIAL ASSISTANT}

Veronika Aurens

London School of Hygiene and Tropical Medicine, Keppel Street, London WC1E 7HT, UK

\section{EDITORS}

Dr Timothy Brewer

McGill University, Montreal, Canada

Professor Anthony R. Fooks

Veterinary Laboratories Agency, Weybridge, UK

Dr Susan Hahné

National Institute for Public Health and the Environment, Bilthoven,

The Netherlands

Dr Craig W. Hedberg

School of Public Health, University of Minnesota, Minneapolis, USA

Professor C. Raina MacIntyre

University of Sydney, Australia

Professor Eduardo Massad

School of Medicine, Sao Paulo, Brazil

Dr Tyrone L. Pitt

Centre for Infections, HPA Colindale, London, UK

Professor Katharina Staerk

Royal Veterinary College, North Mymms, UK

Dr Tim Wreghitt

Clinical Microbiology and Public Health Laboratory, Cambridge, UK

Dr Mark Zuckerman

Kings College Hospital NHS Trust, London, UK

\section{EDITORIAL POLICY}

Epidemiology and Infection publishes reports of research and original findings in subjects related to infectious diseases. Particular emphasis is given to the epidemiology, prevention and control of such diseases, but the field covered is broad and includes microbiological, virological, immunological, clinical and social aspects of infectious diseases of man and animals.

\section{SUBSCRIPTIONS}

Epidemiology and Infection (ISSN 0950-2688) is published monthly, 12 parts forming a volume, by Cambridge University Press, The Edinburgh Building, Shaftesbury Road, Cambridge CB2 8RU, UK/Cambridge University Press, 32 Avenue of the Americas, New York, NY 10013-2473, USA. The subscription price (excluding VAT) including electronic access of Volume 138 (2010) is $£ 728$ net (US \$1430 in the USA, Canada and Mexico). The electronic-only price available to institutional subscribers is $£ 588$ (US $\$ 1140$ in USA, Canada and Mexico). Single parts are $£ 59$ (US \$116 in the USA, Canada and Mexico) plus postage. The print-only price available to institutional subscribers is $£ 645$ (US \$1265 in the USA, Canada and Mexico). Back volumes are also available.

Orders, which must be accompanied by payment, may be sent to a bookseller, subscription agent or direct to the publisher: Cambridge University Press, The Edinburgh Building, Shaftesbury Road, Cambridge CB2 8RU, UK; or in the USA, Canada and Mexico: Cambridge University Press, Journals Fulfillment Department, 100 Brook Hill Drive, West Nyack, New York 10994-2133. EU subscribers (outside the UK) who are not registered for VAT should add VAT at their country's rate. VAT registered subscribers should provide their VAT registration number. Japanese prices for institutions are available from Kinokuniya Company Ltd, PO Box 55, Chitose, Tokyo 156, Japan. Prices include delivery by air.

Periodicals postage paid at New York, NY, and at additional mailing offices.

(C) Cambridge University Press 2010

\section{EDITORIAL BOARD}

P. Aavitsland, Norwegian Institiute of Public Health, Norway

R. M. Anderson, Imperial College of Science, Technology and Medicine, $U K$

M. Bennett, The University of Liverpool, UK

C. S. Block, Hadassah University Hospital, Jerusalem, Israel

M. Evans, HPA Centre for Infections Welsh Unit, Cardiff, UK

C. Fairley, University of Melbourne, Australia

C. P. Farrington, The Open University, Milton Keynes, UK

D. M. Fleming, RCGP Research Unit, Bimingham, UK

K. Forbes, University of Aberdeen, UK

D. Heymann, HPA, London, UK

T. J. Humphrey, University of Bristol, UK

T. J. Marrie, University of Alberta, Canada

E. Miller, HPA Centre for Infections, London, UK

P. Monk, HPA, Leicester, UK

D. Morse, NYS Department of Health, New York, USA

P. P. Mortimer, HPA Virus Reference Laboratory, London, UK

Z. Mulla, Texas Tech University, EI Paso, USA

K. Murray, University of Texas, Houston, USA

G. Balakrish Nair, National Institute of Cholera and Enteric Diseases, Kolkata, India

S. O'Brien, University of Manchester, UK

M. E. Potter, Food and Drug Administration, Atlanta, USA

S. Rankin, University of Pennsylvania, Philadelphia, USA

R. L. Salmon, National Public Health Service for Wales, Cardiff, UK

J. K. Struthers, Coventry and Warwickshire Hospital, UK

J. Stuart, HPA Centre for Infections SW England

R. Tauxe, Centers for Disease Control and Prevention, Atlanta, USA

E. J. Threlfall, HPA, London, UK

A. P. Zavascki, Universidade Federal do Rio Grande do Sul, Brazil
POSTMASTER: send address changes in the USA, Canada and Mexico to: Epidemiology and Infection, Cambridge University Press, 100 Brook Hill Drive, West Nyack, New York 10994-2133. Claims for missing issues should be made immediately on receipt of the subsequent issue.

\section{COPYING}

This journal is registered with the Copyright Clearance Center, 222 Rosewood Drive, Danvers, MA 01923, USA (www.copyright.com). Organizations in the USA who are also registered with CCC may therefore copy material (beyond the limits permitted by sections 107 and 108 of US copyright law) subject to payment to CCC. This consent does not extend to multiple copying for promotional or commercial purposes.

ISI Tear Sheet Service, 3501 Market Street, Philadelphia, PA 19104, USA, is authorized to supply single copies of separate articles for private use only.

Organizations authorized by the Copyright Licensing Agency may also copy material subject to the usual conditions.

For all other use, permission should be sought from Cambridge or the American Branch of Cambridge University Press.

\section{Internet Access}

This journal is included in the Cambridge Journals Online service which can be found at journals.cambridge.org. For further information on other Press titles access cambridge.org

This journal issue has been printed on FSC-certified paper and cover board. FSC is an independent, non-governmental, not-for-profit organization established to promote the responsible management of the world's forests. Please see www.fsc.org for information.

Cover Images: Chicks, by Kovacs Orsi, SXC; Bacillus anthracis, $\mathrm{CDC} /$ Laura Rose; CDC Staff, CDC/ Dr. Scott Smith.

Printed in the United Kingdom by the University Press, Cambridge. 